\title{
Screening Test for Antibiotics in Medicinal Plants (STAMP): Using Powdered Plant Materials Instead of Extracts
}

\author{
Marielle Cascaes Inácio ${ }^{1}$, Fabio Carmona ${ }^{2}$, Tiago Antunes Paz ${ }^{3}$, Maysa Furlan ${ }^{3}$, \\ Fernando Arcanjo da Silva ${ }^{4}$, Bianca Waléria Bertoni ${ }^{4}$, Suzelei de Castro França ${ }^{4}$, \\ Ana Maria Soares Pereira ${ }^{4^{*}}$
}

\begin{abstract}
${ }^{1}$ Departamento de Produção Vegetal, Faculdade de Ciências Agronômicas, Universidade Estadual Paulista "Júlio de Mesquita Filho", Botucatu, Brasil; ${ }^{2}$ Departamento de Puericultura e Pediatria, Faculdade de Medicina de Ribeirão Preto, Universidade de São Paulo, Ribeirão Preto, Brasil; ${ }^{3}$ Departamento de Química Orgânica, Instituto de Química, Universidade Estadual Paulista "Júlio de Mesquita Filho", Araraquara, Brasil; "Unidade de Biotecnologia, Universidade de Ribeirão Preto, Ribeirão Preto, Brasil.

Email: ${ }^{*}$ apereira@unaerp.br
\end{abstract}

Received September $24^{\text {th }}, 2013$; revised October $26^{\text {th }}, 2013$; accepted November $6^{\text {th }}, 2013$

Copyright (C) 2013 Marielle Cascaes Inácio et al. This is an open access article distributed under the Creative Commons Attribution License, which permits unrestricted use, distribution, and reproduction in any medium, provided the original work is properly cited.

\begin{abstract}
Plants are a rich source of antibiotics, but screening all the existing plant species for biological activity using current methods can be time and resource consuming. The present study is to investigate whether powdered plant materials would perform as well as plant extracts in the screening of plants with antimicrobial activity. In the new method proposed (STAMP), we compared in vitro antimicrobial activity of powdered plant materials from 12 species against bacteria and fungi. We confirmed these results with their corresponding aqueous (wet) and hydro-alcoholic extracts and one species testing the antimicrobial activity of two isolated compounds. Compared with hydro-alcoholic extracts, screening using the powdered plant materials correctly identified the majority of the species with antimicrobial activity against Candida albicans (sensitivity $91 \%$, specificity $86 \%$ ), C. parapsilosis (sensitivity $100 \%$, specificity $67 \%$ ), and Staphylococcus aureus (sensitivity 64\%, specificity $86 \%$ ). For bacteria, the method performed better in a $\mathrm{pH}$ of 9.0 . The antimicrobial activity of two compounds isolated from one species (maytenin and netzahualcoyone) confirmed the results. In conclusion, the use of powdered plant materials for screening plants with antimicrobial properties is a cheap, widely available, technically easy, time sparing, reproducible, and sensitive method and can significantly shorten the time and money spent during drug development.
\end{abstract}

Keywords: Herbal Drug; Botanical Drug; Phytotherapics; Natural Products

\section{Introduction}

Infections by multi-drug resistant (MDR) microorganisms are increasing [1], and the number of fully active antibiotic options currently available to treat these infections is extremely limited [2]. Moreover, infections associated with biofilm-forming microorganisms increase exponentially [3,4], representing challenges even for new classes of antifungal compounds such as the echinocandins, lipid formulations of amphotericin B (AMB), and the new triazoles. According to Coates et al., [5] the major problem nowadays is that no matter how potent a new antimicrobial compound is, its therapeutic effective-

"Corresponding author. ness will be relatively short due to the inevitable resistance developed by microorganisms.

It is evident that the pipeline for the development of new, effective antibiotics with activity against MDR organisms looks grim [6]. Soon we may have no medications available in our therapeutic arsenal to treat these highly resistant microbes. This current state of urgency motivated some authors to investigate an innovative approach for inhibition of MDR microorganisms: herbal extracts [2]. In fact, many medicinal plants are used for treatment of infections worldwide [7,8]. A number of in vitro studies have shown antimicrobial activity of herbal extracts, and several clinical trials have been performed to date [7]. 
There are approximately 350,000 plant species in the world [9]. With the current methods, it will take very long before we can screen all of them for all desired pharmacological properties. While all these are being discussed, many areas are being degraded right now and many species will be extinct before being screening for pharmacological properties. Thus, the development of new, accessible, cheap, fast, and simple methods for screening plants for pharmacological effects is highly desirable. It would allow every country in the world, even the poor ones, to start looking into their own vegetation for new medicines. This would have potential to substantially change medical care, as we know it today.

We hypothesized that it is possible to screen plant species for antimicrobial activity by using powdered plant materials instead of plant extracts. We named this method as screening test for antibiotics in medicinal plants (STAMP).

\section{Material and Methods}

\subsection{Reagents and Solvents}

$\mathrm{NaCl}$, ethanol and dichloromethane (all analytical grade) were purchased from Synth (Diadema, SP, Brazil), methanol (HPLC grade) was from JT Baker (USA), ampicillin, amphotericin $\mathrm{B}$, fluconazole, dimethyl sulfoxide (HPLC grade), $\mathrm{CDCl}_{3}(99.96 \%$ D), RPMI-1640 media were purchased from (Sigma-Aldrich, São Paulo, SP, Brazil), gentamicin sulfate was from Ourofino ${ }^{\circledR}$ (Ribeirão Preto, SP, Brazil), bacteriological agar, Sabouraud dextrose, Mueller-Hinton were purchased from Himedia (Curitiba, PR, Brazil). The microorganisms (all ATCC) were purchased from Fundação André Tosello (Campinas-SP, Brazil). Spectra: Spectrophotometer Unico (USA). HPLC system: from Shimadzu (Kyoto, Japan), namely an LC-10-AVP instrument equipped with an auto-injector SIL-10AF, a photodiode array detector SPD-M20A, and a Phenomenex (Torrance, CA, USA) Luna ${ }^{\circledR} \mathrm{C} 18$ column $(250 \times 4.6 \mathrm{~mm}$ i.d.; particle size of 5 $\mu \mathrm{m})$.

\subsection{Plant Materials}

In the experiment we used several different species, as follows: Ocimum gratissimum L. (Lamiaceae), Ocimum basilicum L. (Lamiaceae), Ocimum selloi Benth. (Lamiaceae), Cordia curassavica (Jacq.) Roem. \& Schult. (Boraginaceae), Alternanthera brasiliana (L.) Kuntze. (Amaranthaceae), Physalis angulata L. (Solanaceae), Tinospora cordifolia (Thunb.) Miers (Menispermaceae), Baccharis dracunculifolia D.C. (Asteraceae), Baccharis trimera (Less.) D.C. (Asteraceae), Lippia sidoides Cham. (Verbenaceae), Rapanea leuconeura (Mart.) Mez. (Primulaceae, five different genotypes: 5R1, 5R2, 5R3, 5R4, and SA10), Cochlospermum regium (Schrank.) Pilg.
(Bixaceae), Eugenia punicifolia (Kunth) D.C. (Myrtaceae) and Peritassa campestris (Cambess.) A.C. Sm (Celastraceae). All plants were grown without any pesticides or chemical fertilizers (organically) in gardens.

These species were chosen to be representative of different families, genera, and geographic regions. In addition, we used different plant parts from all studied species-namely, roots, aerial parts, and inner bark. Parts of one of the investigated species, $R$. leuconeura, were collected from individuals of five different genotypes (Table 1). All specieswerecollected inJardinópolis City (São Paulo State, Brazil—Latitude: $21^{\circ} 01^{\prime} 04^{\prime \prime}$, Longitude: $47^{\circ} 45^{\prime} 50^{\prime \prime}$, altitude: $\left.590 \mathrm{~m}\right)$ in February 2011. The $P$. campestris was collected in Ribeirão Preto City (São Paulo State, Brazil-Latitude: $21^{\circ} 10^{\prime} 40^{\prime \prime}$, Longitude: $47^{\circ} 48^{\prime} 36^{\prime \prime}$, altitude: $544 \mathrm{~m}$ ).

Exsiccates of these plants were deposited at the Herbarium of the University of Ribeirão Preto (UNAERP) vouchers, O. gratissimum (HPMU 1329), O. basilicum (HPMU 1455), O. selloi (HPMU 1456), C. curassavica (HPMU 1457), P. angulata (HPMU 1458), T. cordifolia (HPMU 1459), B. dracunculifolia (HPMU 1460), B. trimera (HPMU 1426), L. sidoides (HPMU 1461), $R$.

Table 1. List of plant species, plant organs, and mass of powdered plant materials used in the wells.

\begin{tabular}{|c|c|c|}
\hline Species & Organs used & $\begin{array}{l}\text { Mass of powdered plant } \\
\text { material in each well }(\mathrm{mg})\end{array}$ \\
\hline Ocimum gratissimum & Leaves & 19 \\
\hline Cordia curassavica & Leaves & 22 \\
\hline Althernantera brasiliana & Leaves & 22 \\
\hline Ocimum basilicum & Leaves & 15 \\
\hline Physalis angulata & Leaves & 23 \\
\hline Tinospora cordifolia & Leaves & 16 \\
\hline Baccharis dracunculifolia & Leaves & 17 \\
\hline Bacchatis trimera & Leaves & 19 \\
\hline Lippia sidoides & Leaves & 17 \\
\hline Cochlospermum regium & Roots & 20 \\
\hline Ocimum selolli & Leaves & 22 \\
\hline Eugenia punicifolia & Leaves & 30 \\
\hline Peritassa campestris & Roots & 33 \\
\hline Rapanea leuconeura 5R1 & Barks & 28 \\
\hline Rapanea leuconeura 5R2 & Barks & 28 \\
\hline Rapanea leuconeura 5R3 & Barks & 28 \\
\hline Rapanea leuconeura 5R4 & Barks & 28 \\
\hline Rapanea leuconeura SA10 & Barks & 28 \\
\hline
\end{tabular}


leuconeura (HPMU 1462), C. regium (HPMU 1463), E. punicifolia (HPMU 1464) and P. campestris (HPMU 1414).

To confirm the method's efficiency we evaluated dry powdered plant materials, and compared with wet and hydro-alcoholic extracts of each species, and also the triterpenoids maytenin (tingenone) and netzahualcoyone (Figure 1) isolated from P. campestris.

\subsection{Preparation of Powdered Plant Materials}

The raw plant material was dried in oven at $45^{\circ} \mathrm{C}$ under circulating air, ground in a knife mill and sieved to standardize the particle size (48 mesh). The mass of dry powdered plant material deposited in each well was calculated from its density and the volume of the well (Table 1).

\subsection{Preparation of the Wet Powdered Plant Materials}

The dry powdered plant material was added to distilled water with pipette plastic tips (1:5 w/v, Figure 2). The tips were then wrapped in aluminum sheets and autoclaved for $15 \mathrm{~min}$ at $1 \mathrm{~atm}$ and $121^{\circ} \mathrm{C}$. The proportion of powder and water yielded the resulting mixture to be pasty rather than liquid. The resulting mixture was then called wet powdered plant material. It was not called aqueous extract because it was not filtered. This was done $24 \mathrm{~h}$ before the assays to avoid evaporation of the water. All the mass obtained in this step was used in the wells.

\subsection{Preparation of the Hydro-Alcoholic Extracts}

The hydro-alcoholic extracts (ethanol:water, 1:5 v/v) were obtained by sonication ( 3 times of $20 \mathrm{~min}$ ). After each run, the solution was filtered and more solvent was added to the tart (tart:solvent, 1:2 w/v). After maceration and filtration the extracts were evaporated and lyophi- lized. The lyophilized extracts were added to the plastic tips to allow the insertion into the wells. The amount of lyophilized hydro-alcoholic extract used was that required to fill the well completely.

\subsection{Isolation of Maytenin and Netzahualcoyone and Analysis of Hydro-Alcoholic Root Extract of $P$. campestris}

Maytenin and netzahualcoyone were isolated from root barks of P. campestris as described elsewhere [10]. The identities of the two isolated compounds were confirmed by comparison of their spectroscopic data (UV, MS, ${ }^{1} \mathrm{H}$ and ${ }^{13} \mathrm{C}$ and 2D NMR) with literature values $[11,12]$.

The hydro-alcoholic root extract of $P$. campestris and the chemical standards, maytenin and netzahualcoyone, were dissolved in methanol $(2.5 \mathrm{mg} / \mathrm{ml}$ and $1.0 \mathrm{mg} / \mathrm{ml}$, respectively), filtered through a $0.22 \mu \mathrm{m}$ membrane of a nylon filter, and analyzed by High Performance Liquid Chromatography-Diode Array Detector (HPLC-DAD). The mobile phase was 85:15 (v/v) metanol:water (with $0.1 \%$ formic acid) under isocratic mode at a flow rate of $1 \mathrm{ml} / \mathrm{min}$. The injection volume of the sample and standards was $20 \mu \mathrm{l}$ and the total analytical run time was 30 $\min$. The spectral data were collected over $30 \mathrm{~min}$ in the $200-800 \mathrm{~nm}$ range, and the chromatograms were analyzed and plotted at $420 \mathrm{~nm}$. Compounds present in the sample were identified by comparing retention time (Rt) of the standards.

\subsection{Screening for Antimicrobial Activity}

The STAMP method was developed in agar diffusion (6-mm wells) on 14-cm Petri plates containing $60 \mathrm{ml}$ of Mueller Hinton growth medium ( $\mathrm{pH}$ 7.6). The microorganisms used were Candida albicans ATCC 10231, Candida parapsilosis ATCC 22019, and Staphylococcus aureus ATCC 6538. Inoculum adjustment was done in $0.85 \%$ saline solution and absorbance was measured with

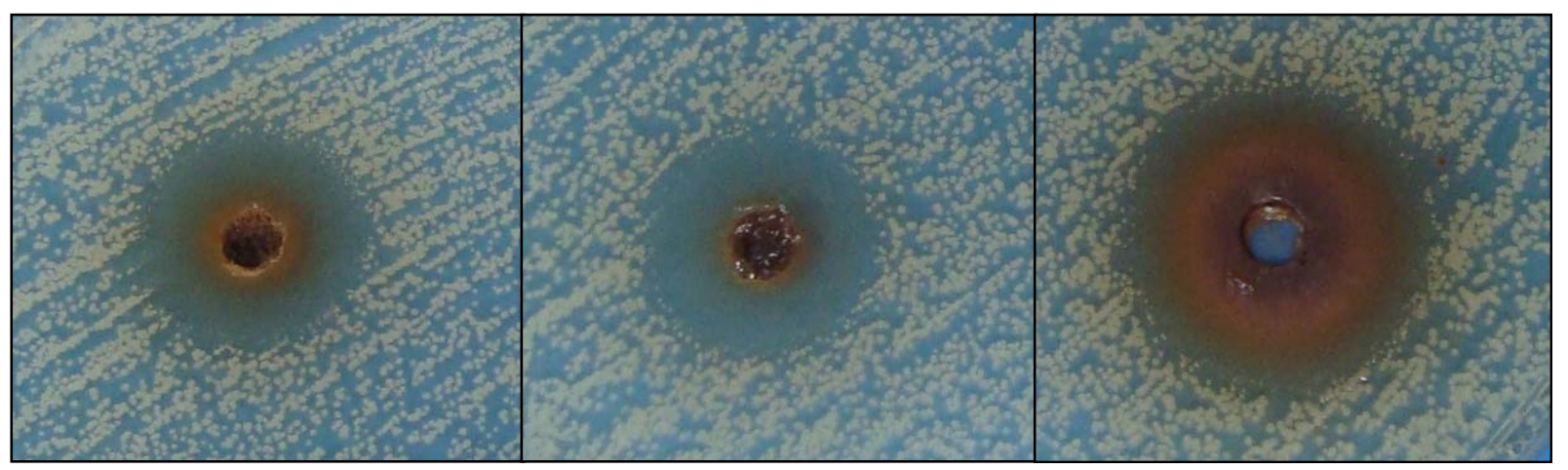

(A)

(B)

(C)

Figure 1. Antifungal activity of different preparations of Cochlospermum regium against Candida albicans in Mueller Hinton growth medium with pH 7.6. Legend: (A) dry powdered plant material; (B) Wet powdered plant material; (C) Hydroalcoholic extract. 


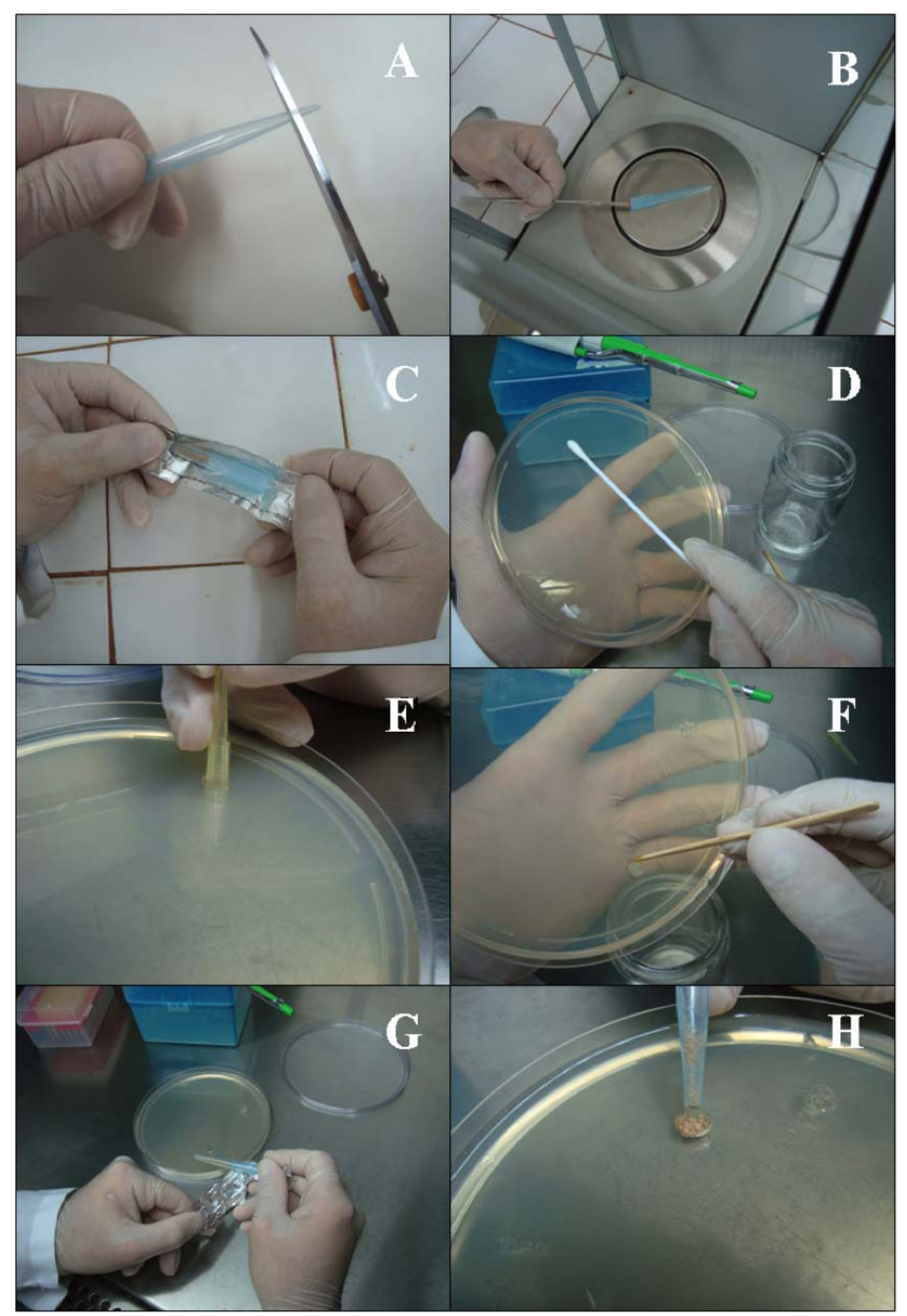

Figure 2. STAMP steps: (A) Preparation of plastic tip to hold the powdered plant materials and lyophilized hydro-alcoholic extracts. (B) Weighting the sample within the tip. (C) Wrapping the tip with aluminum sheet. (D) Inoculation of the microorganism using a sterile swab. (E) and (F) Opening 6-mm wells using upside-down plastic tips. (G) and (H) Introduction of the sample in the well.

a spectrophotometer at $530 \mathrm{~nm}$ with transmittance of $72 \%-75 \%$ (yests) and at $530 \mathrm{~nm}$ with absorbance of $0.10-0.15$ (bacteria). All tests were based on the approved standards CLSI M2-A9 (2006) and M44-A (2003), for bacteria and yeasts, respectively.

The powdered plant materials that exhibited antibacterial activity were also assayed for antibacterial activity in Mueller Hinton medium with a pH of 9.0.

Microorganisms were inoculated into the plates by using a sterile swab that was inserted into the solution containing the microorganism, already adjusted, and twisted several times. Next, the swab was pressed against the wall of the tube to remove solution in excess. The microorganisms were then plated on three different positions so that all the plate's extension was fully covered.

After inoculation of the microorganisms, the 6-mm wells were opened (Figures 2(E) and (F)). Next the powdered plant materials (wet and dry, autoclaved and non-autoclaved), and the lyophilized hydro-alcoholic extracts were added to the wells, as shown in Figure 2. 
The plates were then kept in oven with circulating air at $37^{\circ} \mathrm{C}$ for 24 (bacteria) or 48 (yeasts) h before reading. Readings were done by measuring the halo of inhibition, including the wells, in millimeters.

The standard antibiotics (positive controls) used were fluconazole and ampicillin, both mixed with autoclaved starch (excipient) in concentration of $1 \mathrm{mg} / \mathrm{g}$. A total of $28 \mathrm{mg}$ of the mixture was added to the positive control wells, according to its calculated density. All the experiments were performed in triplicate.

\subsection{Minimum Inhibitory Concentration}

Minimum inhibitory concentrations (MIC) were determined according to standards CLSI M7-A6 (2003) for bacteria and CLSI M27-A2 (2002) for yeasts. The highest concentration used was $100 \mu \mathrm{g} / \mathrm{ml}$. The microorganisms used were Candida albicans ATCC 10231, Candida parapsilosis ATCC 22019 and Staphylococcus aureus ATCC 6538. All the experiments were performed in triplicate. Positive controls were amphotericin B and gentamicin sulfate.

\subsection{Statistical Analysis}

All results were expressed as means and standard deviations (SD). No hypothesis test was done.

\section{Results}

Several dry powdered plant materials were effective against $S$. aureus, namely $P$. angulata, $R$. leuconeura (5R2, 5R3, and 5R4), C. regium, P. campestris, and $E$. punicifolia. These effects were also seen for the correspondent hydro-alcoholic extracts, except for $P$. angulata (Table 2). None of the wet powdered plant materials was effective against $S$. aureus, except for $P$. campestris.

For $C$. albicans, many different dry and wet powdered plant materials showed antifungal activity: $O$. selloi, $L$. sidoides, $R$. leuconeura (5R1, 5R2, 5R3, 5R4, and SA10), C. regium, P. campestris, and E. punicifolia. The antifungal activity was also observed for the correspondent

Table 2. Antimicrobial effect of the different species and preparations against Staphylococcus aureus. Results are expressed as the mean diameter of the halo ( $\mathrm{mm})$.

\begin{tabular}{|c|c|c|c|c|c|}
\hline \multirow[b]{2}{*}{ Family } & \multirow[b]{2}{*}{ Species } & \multirow[b]{2}{*}{ Parts used } & \multicolumn{2}{|c|}{ Powdered plant material } & \multirow{2}{*}{$\begin{array}{c}\text { hydro-alcoholic } \\
\text { extract }\end{array}$} \\
\hline & & & Dry & Wet & \\
\hline Lamiaceae & Ocimum basilicum & Leaves & - & - & - \\
\hline Lamiaceae & Ocimum selloi & Leaves & - & - & $16.00 \pm 1.00$ \\
\hline Boraginaceae & Cordia curassavica & Leaves & - & - & \\
\hline Amaranthaceae & Alternanthera brasiliana & Leaves & - & - & $14.00 \pm 0.00^{\mathrm{a})}$ \\
\hline Solanaceae & Physalis angulata & Leaves & $13.67 \pm 0.58^{\mathrm{a})}$ & - & - \\
\hline Menispermaceae & Tinospora cordifolia & Leaves & - & - & - \\
\hline Asteraceae & Baccharis trimera & Leaves & - & - & - \\
\hline Verbenaceae & Lippia sidoides & Leaves & - & - & $13.33 \pm 0.58$ \\
\hline Primulaceae & Rapanea leuconeura (5R1) & Barks & - & - & $17.67 \pm 1.15$ \\
\hline Primulaceae & Rapanea leuconeura (5R2) & Barks & $12.67 \pm 0.58^{\mathrm{a})}$ & - & $16.67 \pm 2.08$ \\
\hline Primulaceae & Rapanea leuconeura (5R3) & Barks & $9.00 \pm 0.00^{\mathrm{a})}$ & - & $23.67 \pm 0.58$ \\
\hline Primulaceae & Rapanea leuconeura (5R4) & Barks & $8.67 \pm 0.58$ & - & $17.33 \pm 0.58$ \\
\hline Primulaceae & Rapanea leuconeura (SA10) & Barks & - & - & $24.67 \pm 0.58$ \\
\hline Bixaceae & Cochlospermum regium & Roots & - & - & $15.00 \pm 1.00$ \\
\hline Myrtaceae & Eugenia punicifolia & Leaves & $9.00 \pm 1.00$ & - & $16.66 \pm 0.58$ \\
\hline Celastraceae & Ampicillin $1 \mathrm{mg} / \mathrm{g}$ & & $22.67 \pm 2.08$ & - & - \\
\hline
\end{tabular}

a)bacteriostatic effect. 
hydro-alcoholic extracts (Table 3).

Similarly, for C. parapsilosis, many different wet and dry powdered plant materials also showed antifungal activity: L. sidoides, $R$. leuconeura (5R1, 5R2, 5R3, 5R4, and SA10), C. regium, P. campestris, and E. punicifolia. The antifungal activity was also observed for the correspondent hydro-alcoholic extracts (Table 4).

When compared to the results obtained with the hydroalcoholic extracts, the STAMP method was able to identify 10 of the 11 species with activity against $C$. albicans, plus one, yielding a sensitivity of $91 \%$, and a specificity of $86 \%$. For C. parapsilosis, screening with powdered plant materials correctly identified all nine species with potential antifungal activity that were also identified by the hydro-alcoholic extract. Surprisingly, the use of powdered plant materials identified three other species with potential antifungal activity, yielding sensitivity of $100 \%$ and specificity of $67 \%$. For the activity against $S$. aureus, however, the method was able to identify only six of the 12 species identified with hydro-alcoholic extracts, plus one.

After these results, we sought to investigate whether the low performance of the STAMP method for antibacterial activity could be explained by the low solubility of the compounds in a $\mathrm{pH}$ of 7.6. We then repeated the experiments for $S$. aureus, by this time using a Mueller Hinton growth medium with a $\mathrm{pH}$ of 9.0. The results are summarized in Table 5. The alkaline $\mathrm{pH}$ increased the activity of E. punicifolia, and the antibacterial effect of $R$. leuconeura (SA10) was identified, which was not evident in a $\mathrm{pH}$ of 7.6. As a result, for S. aureus the method was able to identify seven of the 12 species identified with hydro-alcoholic extracts, plus one, rendering a sensitivity of $64 \%$, and a specificity of $86 \%$. In general, the higher the medium's $\mathrm{pH}$, the greater the observed antimicrobial activity (Figure 1). The species with antimicrobial activity identified for each microorganism are summarized in Table 6 and Figure 3.

HPLC-DAD chromatogram of the hydro-alcoholic root extract of $P$. campestris gave two major peaks

Table 3. Antimicrobial effect of the different species and preparations against Candida albicans. Results are expressed as the mean diameter of the halo $(\mathrm{mm})$.

\begin{tabular}{|c|c|c|c|c|c|}
\hline \multirow[b]{2}{*}{ Family } & \multirow[b]{2}{*}{ Species } & \multirow[b]{2}{*}{ Parts used } & \multicolumn{2}{|c|}{ Powdered plant material } & \multirow{2}{*}{$\begin{array}{c}\text { hydro-alcoholic } \\
\text { extract }\end{array}$} \\
\hline & & & Dry & Wet & \\
\hline Lamiaceae & Ocimum gratissimum & Leaves & - & - & \\
\hline Lamiaceae & Ocimum basilicum & Leaves & - & - & $25.50 \pm 0.71^{\text {a) }}$ \\
\hline Lamiaceae & Ocimum selloi & Leaves & - & $13.67 \pm 0.58$ & - \\
\hline Boraginaceae & Cordia curassavica & Leaves & - & - & - \\
\hline Amaranthaceae & Alternanthera brasiliana & Leaves & - & - & - \\
\hline Solanaceae & Physalis angulata & Leaves & - & - & - \\
\hline Menispermaceae & Tinospora cordifolia & Leaves & - & - & - \\
\hline Asteraceae & Baccharis trimera & Leaves & - & - & $10.33 \pm 0.58$ \\
\hline Verbenaceae & Lippia sidoides & Leaves & $16.00 \pm 1.00^{\mathrm{a})}$ & $13.33 \pm 0.58^{\mathrm{a})}$ & - \\
\hline Primulaceae & Rapanea leuconeura (5R1) & Barks & $11.00 \pm 2.00$ & $16.67 \pm 0.58$ & $28.67 \pm 0.58^{\mathrm{a})}$ \\
\hline Primulaceae & Rapanea leuconeura (5R2) & Barks & $15.33 \pm 0.58^{\mathrm{a})}$ & $20.33 \pm 0.58^{\mathrm{a})}$ & $27.00 \pm 1.00$ \\
\hline Primulaceae & Rapanea leuconeura (5R3) & Barks & $22.67 \pm 0.58$ & $22.33 \pm 0.58$ & $15.00 \pm 1.00$ \\
\hline Primulaceae & Rapanea leuconeura (5R4) & Barks & $16.33 \pm 0.58$ & $20.33 \pm 1.15$ & $31.67 \pm 0.58$ \\
\hline Primulaceae & Rapanea leuconeura (SA10) & Barks & $18.67 \pm 0.58^{\mathrm{a})}$ & $16.67 \pm 0.58^{\mathrm{a})}$ & $24.67 \pm 0.58$ \\
\hline Bixaceae & Cochlospermum regium & Roots & $23.67 \pm 0.58$ & $23.67 \pm 0.58$ & $20.33 \pm 0.58$ \\
\hline Myrtaceae & Eugenia punicifolia & Leaves & $22.67 \pm 1.15$ & $20.33 \pm 0.58$ & $32.00 \pm 1.00$ \\
\hline Celastraceae & Fluconazole $1 \mathrm{mg} / \mathrm{g}$ & & $27.67 \pm 2.52$ & & $25.33 \pm 0.58^{\mathrm{a})}$ \\
\hline
\end{tabular}

${ }^{a)}$ Fungistatic effect. 
Table 4. Antimicrobial effect of the different species and preparations against Candida parapsilosis. Results are expressed as the mean diameter of the halo $(\mathrm{mm})$.

\begin{tabular}{|c|c|c|c|c|c|}
\hline \multirow[b]{2}{*}{ Family } & \multirow[b]{2}{*}{ Species } & \multirow[b]{2}{*}{ Parts used } & \multicolumn{2}{|c|}{ Powdered plant material } & \multirow{2}{*}{$\begin{array}{c}\text { hydro-alcoholic } \\
\text { extract }\end{array}$} \\
\hline & & & Dry & Wet & \\
\hline Lamiaceae & Ocimum gratissimum & Leaves & - & $11.33 \pm 0.58^{\mathrm{a})}$ & - \\
\hline Lamiaceae & Ocimum basilicum & Leaves & - & - & - \\
\hline Lamiaceae & Ocimum selloi & Leaves & $19.67 \pm 0.58^{\mathrm{a})}$ & $15.67 \pm 0.58^{\mathrm{a})}$ & - \\
\hline Boraginaceae & Cordia curassavica & Leaves & - & - & - \\
\hline Amaranthaceae & Alternanthera brasiliana & Leaves & - & - & - \\
\hline Solanaceae & Physalis angulata & Leaves & - & - & - \\
\hline Menispermaceae & Tinospora cordifolia & Leaves & - & - & - \\
\hline Asteraceae & Baccharis dracunculifolia & Leaves & - & $17.33 \pm 0.58^{\mathrm{a})}$ & \\
\hline Asteraceae & Baccharis trimera & Leaves & - & - & - \\
\hline Verbenaceae & Lippia sidoides & Leaves & - & $14.33 \pm 0.58^{\mathrm{a})}$ & $15.67 \pm 0.58^{\mathrm{a})}$ \\
\hline Primulaceae & Rapanea leuconeura (5R1) & Barks & $15.67 \pm 0.58^{\mathrm{a})}$ & $20.00 \pm 0.58^{\mathrm{a})}$ & $30.33 \pm 0.58$ \\
\hline Primulaceae & Rapanea leuconeura (5R2) & Barks & $18.67 \pm 0.58$ & $19.67 \pm 0.58^{\mathrm{a})}$ & $29.33 \pm 0.58$ \\
\hline Primulaceae & Rapanea leuconeura (5R3) & Barks & $21.33 \pm 0.58$ & $21.67 \pm 0.58$ & $32.67 \pm 0.58$ \\
\hline Primulaceae & Rapanea leuconeura (5R4) & Barks & $16.67 \pm 0.58^{\mathrm{a})}$ & $18.67 \pm 0.58$ & $26.67 \pm 0.58$ \\
\hline Primulaceae & Rapanea leuconeura (SA10) & Barks & $21.00 \pm 0.00^{\mathrm{a})}$ & $17.67 \pm 0.58^{\mathrm{a})}$ & $16.67 \pm 0.58$ \\
\hline Bixaceae & Cochlospermum regium & Roots & $24.00 \pm 1.00^{\mathrm{a})}$ & $23.50 \pm 0.71$ & $34.67 \pm 0.58$ \\
\hline Myrtaceae & Eugenia punicifolia & Leaves & $22.67 \pm 0.58$ & $23.33 \pm 0.58$ & $31.00 \pm 0.00$ \\
\hline \multirow[t]{2}{*}{ Celastraceae } & Peritassa campestris & Roots & $21.33 \pm 0.58^{\mathrm{a})}$ & $19.33 \pm 0.58^{\mathrm{a})}$ & $28.33 \pm 0.58^{\mathrm{a})}$ \\
\hline & Fluconazole $1 \mathrm{mg} / \mathrm{g}$ & & $33.25 \pm 1.26$ & - & - \\
\hline
\end{tabular}

${ }^{a)}$ Fungistatic effect.

Table 5. Activity of the dry powdered plant material against Staphylococcus aureus in Mueller Hinton growth medium with a pH of 9.0. Results are expressed as the mean diameter of the halo (mm).

\begin{tabular}{cc}
\hline Species & S. aureus \\
\hline Ocimum selloi & - \\
Alternanthera brasiliana & - \\
Baccharis dracunculifolia & - \\
Lippia sidoides & - \\
Rapanea leuconeura (SA10) & $10.00 \pm 0.00^{\mathrm{a})}$ \\
Cochlospermum regium & - \\
Eugenia punicifolia & $12.00 \pm 1.00^{\mathrm{a})}$ \\
Ampicillin 1 mg/g & $11.25 \pm 1.89$ \\
\hline
\end{tabular}

${ }^{a}$ Bacteriostatic effect.

(Figure 4) at retention times (Rt) of $8.7 \mathrm{~min}$ and 10.1

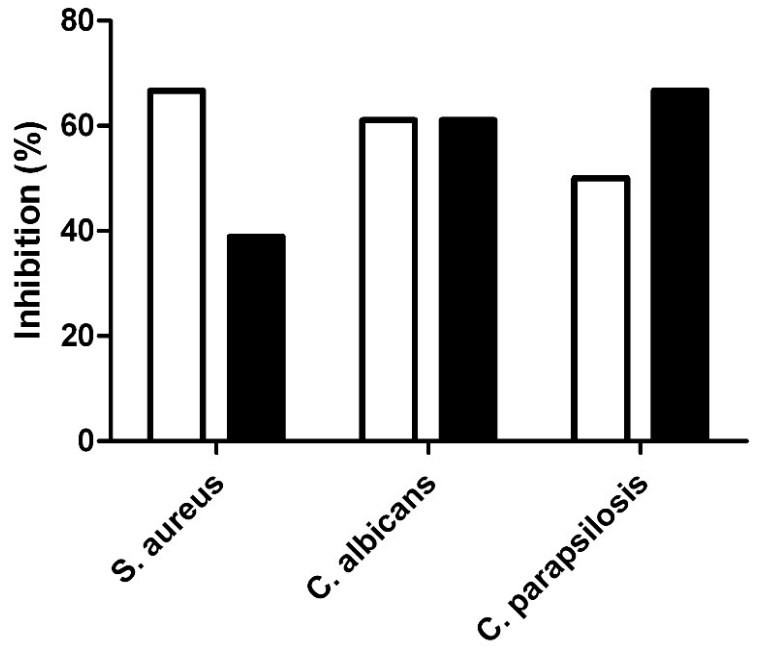

Hydroalcoholic extract

Figure 3. Proportion of plant species with antimicrobial activity among all tested species, according to different microorganisms and extracts. 


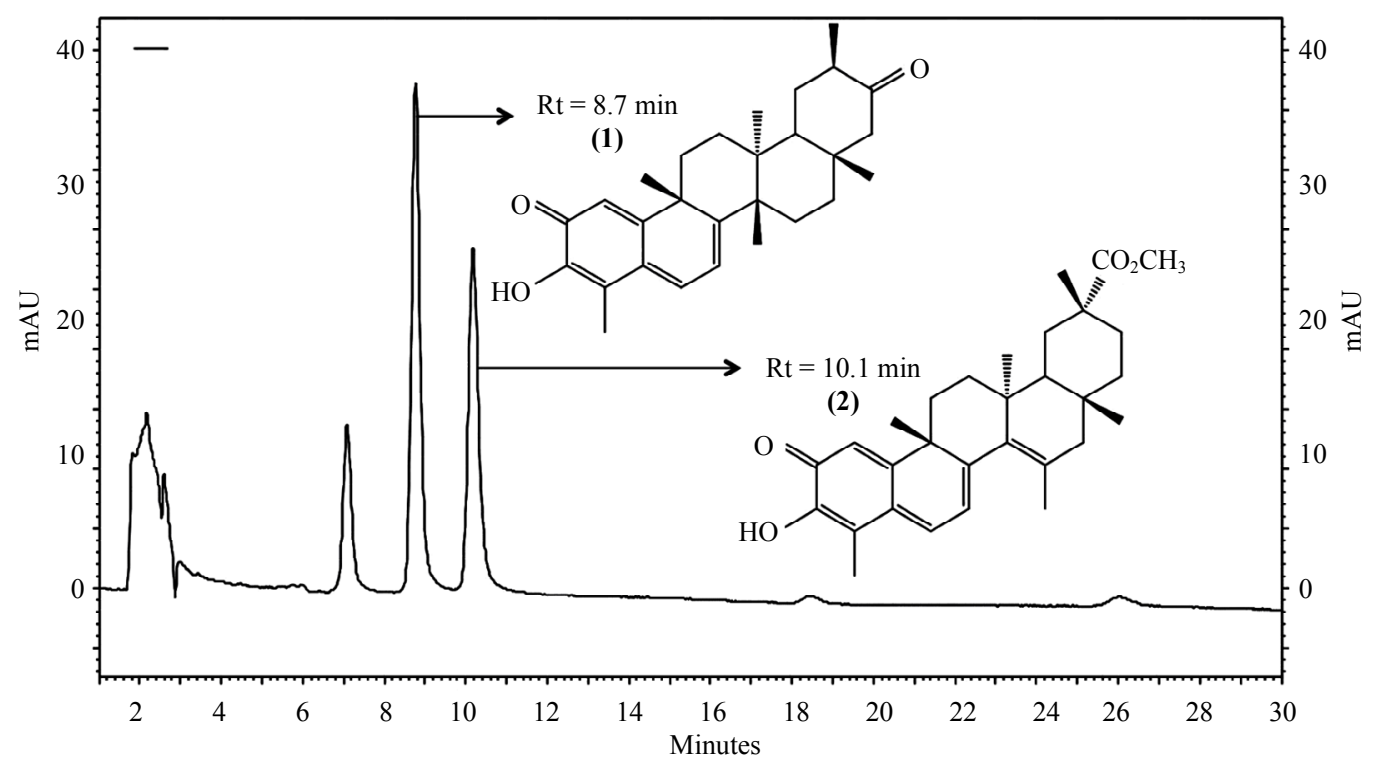

Figure 4. Chromatogram of Peritassa campestris hydro-alcoholic root extract by HPLC-DAD analysis. Peak identification: maytenin (1) and netzahualcoyone (2). Conditions: mobile phase: 85:15 (v/v) metanol:water (with $0.1 \%$ formic acid); injection volume: $20 \mu \mathrm{L}$; detection $\lambda=420 \mathrm{~nm}$; flow rate: $01.0 \mathrm{ml} / \mathrm{min}$.

Table 6. Species identified as having antimicrobial activity according to the type of extract used.

\begin{tabular}{|c|c|c|c|c|c|c|}
\hline \multirow[b]{2}{*}{ Species } & \multicolumn{2}{|c|}{$\begin{array}{c}\text { Staphylococcus } \\
\text { aureus }\end{array}$} & \multicolumn{2}{|c|}{$\begin{array}{l}\text { Candida } \\
\text { albicans }\end{array}$} & \multicolumn{2}{|c|}{$\begin{array}{c}\text { Candida } \\
\text { parapsilosis }\end{array}$} \\
\hline & $\mathrm{PD}^{\mathrm{a})}$ & $\mathrm{HE}^{\mathrm{b})}$ & $\mathrm{PD}$ & $\mathrm{HE}$ & $\mathrm{PD}$ & $\mathrm{HE}$ \\
\hline Ocimum gratissimum & & & & + & + & \\
\hline Ocimum selloi & & + & + & & + & \\
\hline Alternanthera brasiliana & & + & & & & \\
\hline Physalis angulata & + & & & & & \\
\hline Baccharis dracunculifolia & & + & + & + & + & \\
\hline Lippia sidoides & & + & + & + & + & + \\
\hline Rapanea leuconeura (5R1) & & + & + & + & + & + \\
\hline Rapanea leuconeura (5R2) & + & + & + & + & + & + \\
\hline Rapanea leuconeura (5R3) & + & + & + & + & + & + \\
\hline Rapanea leuconeura (5R4) & + & + & + & + & + & + \\
\hline Rapanea leuconeura (SA10) & $\left.+^{*}\right)$ & + & + & + & + & + \\
\hline Cochlospermum regium & + & + & + & + & + & + \\
\hline Peritassa campestris & + & + & + & + & + & + \\
\hline Eugenia punicifolia & $++^{* *}$ & + & + & + & + & + \\
\hline
\end{tabular}

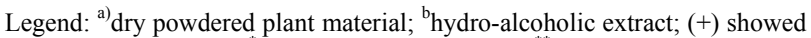
antimicrobial activity; ${ }^{*}$ observed in a $\mathrm{pH}$ of $9.0 ;{ }^{* *}$ effect was stronger in a $\mathrm{pH}$ of 9.0 .

which were identified as maytenin and netzahualcoyone, respectively, by matching the Rt with those of the corresponding standards. These substances showed antimicro- bial activity mainly against S. aureus (MIC of $0.78 \mu \mathrm{g} / \mathrm{ml}$ ), but also C. albicans and C. parapsilosis (Table 7).

\section{Discussion}

This is the first report on the use of powdered plant materials on screening tests for antimicrobial activity. We called this the STAMP method. We have shown that this method is best suitable for screening of plants with antifungal properties, since it has higher sensitivity and specificity compared to the use of hydro-alcoholic extracts. In addition, the method can also be used for screening of plants with antibacterial activity, as long as the $\mathrm{pH}$ is increased to 9.0 .

In a similar experiment, Miyasaki et al. [2] screened 60 different plants for antimicrobial activity, and found that 18 of them had the desired effect. The lack of correlation between the amount of herbal extract required to fill the indented agar well and its ability to diffuse out of the well onto the Mueller Hinton agar plate were probably due to their different solubility in the aqueous environment and to the molecular size of its chemical constituents.

We have experienced a similar issue when testing for antibacterial activity. However, when we used a medium with an alkaline $\mathrm{pH}$, the antibacterial activity of many species became evident. Interestingly, the alkaline $\mathrm{pH}$ totally reduced the activity of ampicillin against against $S$. aureus by half. The intracellular $\mathrm{pH}$ of microorganisms does not vary significantly in response to variations in extracellular $\mathrm{pH}$. However, extracellular $\mathrm{pH}$ can affect the transport of certain compounds across the cell mem- 
Table 7. Minimum inhibitory concentration (MIC, $\mu \mathrm{g} / \mathrm{ml})$ values of quinone-methide triterpenoids isolated from Peritassa campestris against Staphylococus aureus, Candida albicans, and Candida parapsilosis.

\begin{tabular}{|c|c|c|c|c|}
\hline Microorganisms & Maytenin & Netzahualcoyone & Gentamicin & $\begin{array}{c}\text { Amphotericin } \\
\text { B }\end{array}$ \\
\hline S. aureus & 0.78 & 0.78 & 4.00 & *) \\
\hline C. albicans & 50.00 & 50.00 & *) & 2.00 \\
\hline C. parapsilosis & 25.00 & 25.00 & *) & 2.00 \\
\hline
\end{tabular}

${ }^{*}$ Not evaluated.

brane [13]. Therefore, it is evident that any alteration in $\mathrm{pH}$ can enhance the passage across the cell membrane of water-soluble secondary metabolites with antimicrobial activity, like flavonoids, anthocyanins, and alkaloids. According to other authors, any increase in $\mathrm{pH}$ can potentiate interactions between polyphenols and membrane surfaces through deprotonation of hydroxyl groups [14].

The antimicrobial activity of the isolated compounds from $P$. campestris confirmed the results obtained with STAMP method. P. campestris was chosen for the MIC experiment because it contains substances named quinonemethide triterpenoids, such as maytenin and netzahualcoyone, that are chemotaxonomic markers of the Celastraceae family, and that exhibit a myriad of biological activities $[15,16]$. The results we obtained with the powdered plant material of $P$. campestris using the STAMP method and the results of maytenin and netzahualcoyone using the MIC method were similar and showed greatest antimicrobial activity against $S$. aureus, followed by C. parapsilosis and C. albicans. These results were also similar to those obtained by Elhag et al. [17], with a similar low MIC against $S$. aureus (0.6 $\mu \mathrm{g} / \mathrm{ml}$ ). Regarding to the yeasts, a study by Gullo et al. [18] showed results similar to ours, with a lower MIC of maytenin for C. parapsilosis and higher for C. albicans $(15.62$ e $62.50 \mu \mathrm{g} / \mathrm{ml}$, respectively). All these results support the work of Moujir et al. [19] showing that triterpenoids exhibit antimicrobial activity for Gram-positive bacteria and yeasts.

Our results are very promising because the technology required for the successful discovery, development, and production of botanical drugs is not yet in place, and efforts required for their emergence should be substantial [20]. The current method of drug discovery, the so-called high throughput screening (HTS), is not easily adaptable to complex mixtures produced from natural sources. This is mainly due to the high cost per sample, complexity of resupply, difficulty in isolation and characterization of actives, lack of reproducibility, and interference from compounds in complex mixtures [21]. In addition, isolation and purification of the active principles from an exceptionally complex matrix are one of the major bottle- necks affecting natural product discovery, and this relatively simplistic and reductionist approach may lead to inconclusive findings in clinical trials [20,22].

More recently the pharmaceutical industry has avoided three situations concerning the use of medicinal plant compounds in the formulation of bioproducts: a) isolation of pure substances from complex mixtures, which is expensive and requires long-term working; b) production of crude extracts, which present poor solubility; and c) use of species with reduced supply [23].

Many natural molecules, when isolated, are not watersoluble, and consequently have poor bioavailability. But if one takes the whole package, that is, the phytocomplex, the interaction between all the compounds present within the plant can actually increase solubility in water and bioavailability. In our experiment, the observed antimicrobial effect can only be attributable to water-soluble compounds, since we did not use any extraction technique and the media was aqueous. Therefore, by using this new screening method, we can be sure that the major compounds responsible for the pharmacological property will potentially have a fairly good bioavailability. Increasing the medium's $\mathrm{pH}$ allowed the identification of additional species with the properties of interest.

Given the urgency of discovering new antibiotics, it is highly desirable to screen as many plant species as possible, but this can take a very long time. Many factors may increase the time needed for the screening of a plant. First, different plant parts can have different chemical compositions. Second, plants can have different chemotypes, resulting in different chemical profiles. Third, climate and soil type can alter the plant's chemical composition. Lastly, different plant extracts with different solvents have to be obtained and tested. The preparation of different herbal extracts consumes time and both human and financial resources. We believe that the new method we present here can effectively contribute to the field, because it requires less time since no extraction method is needed. This will allow more cost-effective research, increasing the possibility of finding new drugs with antimicrobial activity.

\section{Conclusion}

In conclusion, the STAMP method, which uses powdered plant materials instead of plant extracts, is a cheap, widely available, technically easy, time sparing, reproducible, and sensitive method of screening plant species for antimicrobial properties, and can significantly shorten the time and money spent during drug development. The method we propose selected many species with potential antimicrobial activity for future phytochemical investigations aiming at the relationship between chemical structure and biological activity. We have also shown that this method is suitable for screening different geno- 
types of a single species, and different plant organs.

\section{Acknowledgements}

We thank the Fundação de Amparo à Pesquisa do Estado de São Paulo (FAPESP, grant\# 2010/15168-6) for financial support and Coordenação de Aperfeiçoamento de Pessoal de Nível Superior (CAPES). We also thank to Msc. Camila Hernandes for her support on MIC experiments, and to Dalma M. S. Rodrigues, MD, for her invaluable contribution on manuscript revision.

\section{REFERENCES}

[1] F. Carmona, S. I. Prado, M. F. I. Silva, G. G. Gaspar, F. Bellissimo-Rodrigues, R. Martinez, A. K. Matsuno and A. P. Carlotti, "Vancomycin-Resistant Enterococcus Outbreak in a Pediatric Intensive Care Unit: Report of Successful Interventions for Control and Prevention," Brazilian Journal of Medical and Biological Research, Vol. 45, No. 2, 2012, pp. 158-162. http://dx.doi.org/10.1590/S0100-879X2012007500005

[2] Y, Miyasaki, W. S. Nichols, M. A. Morgan, J. A. Kwan, M. M. Van Benschoten, P. E. Kittell and W. D. Hardy, "Screening of Herbal Extracts against Multi-Drug Resistant Acinetobacter baumannii," Phytotherapy Research, Vol. 24, No. 8, 2010, pp. 1202-1206.

[3] M. W. Harding, L. L. R. Marques, R. J. Howard and M. E. Olson, "Can Filamentous Fungi Form Biofilms?" Trends in Microbiology, Vol. 17, No. 11, 2009, pp. 475-480. http://dx.doi.org/10.1016/i.tim.2009.08.007

[4] W. M. Dunne, "Bacterial Adhesion: Seen Any Good Biofilms Lately?" Clinical Microbiology Reviews, Vol. 15, No. 2, 2002, pp. 155-166.

http://dx.doi.org/10.1128/CMR.15.2.155-166.2002

[5] A. Coates, Y. Hu, R. Bax and C. Page, "The Future Challenges Facing the Development of New Antimicrobial Drugs," Nature Reviews Drug Discovery, Vol. 1, No. 11, 2002, pp. 895-910.

http://dx.doi.org/10.1038/nrd940

[6] H. W. Boucher, G. H. Talbot, J. S. Bradley, J. E. Edwards, D. Gilbert, L. B. Rice, M. Scheld, B. Spellberg and J. Bartlett, "Bad Bugs, No Drugs: No ESKAPE! An Update from the Infectious Diseases Society of America," Clinical Infectious Diseases, Vol. 48, No. 1, 2009, pp. 1-12. http://dx.doi.org/10.1086/595011

[7] K. W. Martin and E. Ernst, "Herbal Medicines for Treatment of Bacterial Infections: A Review of Controlled Clinical Trials," Journal of Antimicrobial Chemotherapy, Vol. 51, No. 2. 2003, pp. 241-246. http://dx.doi.org/10.1093/jac/dkg087

[8] M. R. S. Zaidan, A. Noor Rain, A. R. Badrul, A. Adlin, A. Norazah and I. Zakiah, "In Vitro Screening of Five Local Medicinal Plants for Antibacterial Activity Using Disc Diffusion Method," Trop Biomed, Vol. 22, No. 2, 2005, pp. 165-170.

[9] A. J. Paton, N. A. Brummitt, R. Govaerts, K. Harman, S. Hinchcliffe, B. Allkin and E. N. Lughadha, "Towards
Target 1 of the Global Strategy for Plant Conservation: A Working List of All Known Plant Species-Progress and Prospects," Taxon, Vol. 57, No. 2, 2008, pp. 602-611.

[10] J. Corsino, P. R. de Carvalho, M. J. Kato, L. R. Latorre, O. M. Oliveira, A. R. Araujo, V. S Bolzani, S. C. Franca, A. M. S. Pereira and M. Furlan, "Biosynthesis of Friedelane and Quinonemethide Triterpenoids Is Compartmentalized in Maytenus aquifolium and Salacia campestris," Phytochemistry, Vol. 55, No. 7, 2000, pp. 741-748. http://dx.doi.org/10.1016/S0031-9422(00)00285-5

[11] A. H. Jeller, D. H. S. Silva, L. M. Lião, V. S. Bolzani and M. Furlan, "Antioxidant Phenolic and Quinonemethide Triterpenes from Cheiloclinium cognatum," Phytochemistry, Vol. 65, No. 13, 2004, pp. 1977-1982. http://dx.doi.org/10.1016/j.phytochem.2004.03.039

[12] O. Ngassapa, D. D. Soejarto, J. M. Pezzuto and N. R. Farnsworth, "Quinone-Methide Triterpenes and Salaspermic Acid from Kokoona ochracea," Journal of Natural Products, Vol. 57, No. 1, 1994, pp. 1-8. http://dx.doi.org/10.1021/np50103a001

[13] M. Carels and D. Shepherd, "The Effect of $\mathrm{pH}$ and Amino Acids on Conidiation and Pigment Production of Monascus major ATCC 16362 and Monascus rubiginosus ATCC 16367 in Submerged Shaken Culture," Canadian Journal of Microbiology, Vol. 24, No. 11, 1978, pp. 1346-1357. http://dx.doi.org/10.1139/m78-217

[14] A. Scalbertn and G. Williamson, "Dietary Intake and Bioavailability of Polyphenols," Journal of Nutrition, Vo. 130, Suppl. 8S, 2000, pp. 2073-2085.

[15] T. Akase, T. Shimada, Y. Harasawa, Y. Ikeya, E. Nagai, S. Iizuka, G. Nakagami, S. Iizaka, H. Sanada and M. Aburada, "Preventive Effects of Salacia reticulata on Obesity and Metabolic Disorders in TSOD Mice," Evidence-Based Complementary and Alternative Medicine, Vol. 2011, No. 484590, 2011, pp. 1-10. http://dx.doi.org/10.1093/ecam/nep052

[16] S. M. Oramas-Royo, H. Chavez, P. Martin-Rodiguez, L. Fernand Ez-Perez, A. G. Ravelo and A. Estevez-Braun, "Cytotoxic Triterpenoids from Maytenus retusa," Journal of Natural Products, Vol. 73, No. 12, 2010, pp. 20292034. http://dx.doi.org/10.1021/np100517u

[17] H. Elhag, J. S. Mossa and M. M. El-Olemy, "Antimicrobial and Cytotoxic Activity of the Extracts of Khat Callus Cultures," In: J. Janick, Ed., Perspectives on New Crops and New Uses, ASHS Press, Alexandria, 1999, pp. 463-466.

[18] F. P. Gullo, J. C. Sardi, V. A. Santos, F. Sangalli-Leite, N. S. Pitangui, S. A. Rossi, E. S. A. C. de Paula, L. A. Soares, J. F. Silva, H. C. Oliveira, M. Furlan, D. H. Silva, V. S. Bolzani, M. J. Mendes-Giannini and A. M. FuscoAlmeida, "Antifungal Activity of Maytenin and Pristimerin," Evidence-Based Complementary and Alternative Medicine, Vol. 2012, 2012, pp. 1-6.

http://dx.doi.org/10.1155/2012/340787

[19] L. Moujir, A. M. Gutierrez-Navarro, A. G. Gonzalez, A. G. Ravelo and J. G. Luis, "Mode of Action of Netzahualcoyone," Antimicrobial Agents and Chemotherapy, Vol. 35, No. 1, 1991, pp. 211-213. http://dx.doi.org/10.1128/AAC.35.1.211 
[20] I, Raskin and C. Ripoll, "Can an Apple a Day Keep the Doctor Away?" Current Pharmaceutical Design, Vol. 10, No. 24, 2004, pp. 3419-3429. http://dx.doi.org/10.2174/1381612043383070

[21] B. Schmidt, D. Ribnicky, A. Poulev, S. Logendra, W. Cefalu and I. Raskin, "A Natural History of Botanical Therapeutics," Metabolism, Vol. 57, No. 1, 2008, pp. S3S9. http://dx.doi.org/10.1016/j.metabol.2008.03.001
[22] E. M. Williamson, "Synergy and Other Interactions in Phytomedicines," Phytomedicine, Vol. 8, No. 5, 2001, pp. 401-409. http://dx.doi.org/10.1078/0944-7113-00060

[23] J. W. Li and J. C. Vederas, "Drug Discovery and Natural Products: End of an Era or an Endless Frontier?" Science, Vol. 325, No. 5937, 2009, pp. 161-165.

http://dx.doi.org/10.1126/science. 1168243 